\title{
Drinking Water Issue in North-West Sinai: The Problem and Solution in a Case Study
}

\author{
H.I. Abdel-Shafy ${ }^{\#}$, M.A. Salem ${ }^{*}$, Mona S.M. Mansour ${ }^{* *}$, \\ M.A. El-Khateeb and Sally H. Abdel-Shafy \\ National Research Center, Dokki, Cairo, Serabium Wastewater \\ Treatment Plant, Ismailia, ${ }^{* *}$ Analysis \& Evaluation \\ Department, Egyptian Petroleum Research Institute, 1 Ahmed \\ El-Zomor Street, Nasr City, Cairo, Egypt.
}

\begin{abstract}
RINKING water has received considerable attention recently. However, misuse and mismanagement have resulted in a rapid and widespread decline in source-water quality and supply. Drinking water issue in Sinai is the subject of the present study. The selected area is El-Taqaddum Village and the surrounding region in NorthWest Sinai. Different samples of the potable water from the drinking water treatment plant were taken during this study period. Physical and chemical characteristics of the water investigation indicated that $\mathrm{pH}$ value ranged from 6.8 to 8.4 . Temperatures varied from $17^{\circ}$ to $35^{\circ}$. Turbidity ranged from 0.30 to 0.78 as NTU. The level of metals in the studied water can be arranged according to the following decreasing order:- sodium > potassium > aluminum > iron > manganese in the magnitude of :- $150: 35: 4: 2: 1$ respectively. Comparatively high values of $\mathrm{Al}, \mathrm{Fe}$ and $\mathrm{Mn}$ indicated the input of such metals in the raw canal water. It was, therefore, recommended to enhance the settling process of raw canal water before treatment. Storing drinking water for more than two days causes the disappearance of chlorine down to zero. It is strongly recommended that the drinking water of this village should be freshly supplied. This should be associated with a supply of fresh water through the Canal. A continuous follow up of the physical, chemical and biological examination of this drinking water should be carried out precisely. The present investigation showed that the most possible solution is to maintain an initial $\mathrm{Cl}_{2}$ concentration at $2 \mathrm{mg} / \mathrm{l}$ and the storing period should not exceed 2 days. To make this clear, residual chlorine in all drinking water supply should be within the permissible limits for safety of the residents. Otherwise, outbreak of epidemic diseases could be at high risk for these poor residents. A continuous flow of the water sources should be supplied to protect the residents of this area with safe treated drinking water.
\end{abstract}

Sinai Peninsula is a unique environment. Over the years, it has been subjected to flora $^{(1-4)}$ and microflora ${ }^{(5,6)}$ investigations. With a rainfall of $<100 \mathrm{~mm}$ per year, the major limitations for agricultural development are the available water resources ${ }^{(22)}$. Therefore, additional water should be secured, e.g. the reuse of agriculture drainage water and / or adequate treated wastewater ${ }^{(7,8)}$. In this respect, El-Salam (peace) canal is considered as a unique project brings the Nile

"Corresponding author email: hshafywater@yahoo.com and waterbiotech@yahoo.com 
water to the eastern deserts of North Sinai; originating from the River Nile at 210 $\mathrm{km}$ on Damietta branch and running south east ca. $89.4 \mathrm{~km}$. The canal is, further, crosses the Suez Canal through a siphon to the Sinai peninsula extending about $176 \mathrm{~km}$ eastward in North Sinai. It is planned to deliver $4.45 \times 10^{9} \mathrm{~m}^{3}$ water, provided by the River Nile (about $2.11 \times 10^{9} \mathrm{~m}^{3}$ ) mixed at (ca. $1: 1$, v/v) with about $2.34 \times 10^{9} \mathrm{~m}^{3}$ of drainage water (El-Serw and Hadous drains) ${ }^{(9,10)}$. The canal is planned to provide water for irrigating and cultivating about ca. 150,000 hectares in North Sinai. The total targeted is to cultivate ca. 248,000 hectares. In this respect, water is to be checked and analyzed periodically during the years of plantation to monitor and readjust the ratio of mixing in the light of changes in quality of both soil and waters.

So far, in situ and laboratory studies concentrated on the western part of the canal before crossing the Suez Canal ${ }^{(23)}$. The water quality has been examined by the physical and chemical properties (not microbiologically) along El-Serw and Hadous drains since 1997 as well as the western course prior the Suez Canal siphon ${ }^{(7,10-12)}$.

In South Sinai Peninsula, along the Red Sea, tourism is the most dominating industry. Water supply is secured by either desalination of the sea or the ground brackish water, or by piped or transported trucked water from the Nile ${ }^{(13)}$. Despite the water scarcity, unfortunately, reuse of treated wastewater is not widely applied ${ }^{(14)}$. Adequate treated wastewater could be used for irrigation and non-potable domestic purposes, thus reducing potable water demand ${ }^{(15)}$. Due to the excessive costs of desalination and water transportation from the Nile, the price of potable water in this tourist region is about ten times higher than in Cairo. The important factor that contributes to price escalation of water supply is the dependence on privately-owned small size desalination units, i.e. no economies of scale.

The present study region is a promising continuous population and economic growth. The problem is that economic development is not matched by adequate water resources. The gap between water demand and water availability is expected to reach $1 \mathrm{Mm}^{3} / \mathrm{d}$ (million cubic meters per day) in South Sinai by the year $2020^{(16,17)}$. Due to limited Nile resources and high transportation costs, the scenario for development of the region has to be based on seawater or brackish water desalination and reuse of treated wastewater to satisfy all demands, as well as water demand management (decrease water demand and use). It is important that the private sector must be encouraged to invest in water projects to relieve increasing financial pressures on the government, and to satisfy increasing water demand. A detailed study of the situation in this region with modeling of possible water management scenarios for projects will aid investors (both public and private) in the decision making process ${ }^{(18)}$.

El-Taqaddum Village and the surround area in North-West Sinai, locates in the western side of the peninsula. It can be reached from Ismailia City by car that

Egypt. J. Chem. 59, No. 2 (2016) 
would take between 30 to $45 \mathrm{~min}$. The distance is about $65 \mathrm{~km}$. The village depends on fresh water treatment plant for drinking. The source of water is supplied by fresh water from an extension of Ismailia Canal. However, the supply of this water is very limited. This source of fresh water is regulated to be 6 days for the drinking water treatment plant and the following 6 days for irrigating the agriculture land within the area. Due to this restricted water resources, the people of El-Taqaddum area in Sinai used to store their drinking water in PVC tanks to supply them with their demand of water. The quality of this water should meet the required standards and guidelines for human use. Otherwise, hazardous health impact will be developed including kidney failure and / or spreading of epidemic diseases. However, such quality of this water is expected to be declined greatly by time.

Therefore, it was found essential to study the physical and chemical characteristics of drinking water from selected houses with El-Taqaddum Village, Sinai to identify water quality that might affect human health. Correlation with the Egyptian regulations / guidelines and the effect on public health were evaluated.

\section{Materials and Methods}

An intensive program for the sampling of drinking water from selected seven different houses at El-Taqaddum village, Sinai was designed during the period from August, 2015 till January, 2016. The samples were taken bi-monthly. All the drinking water samples were taken from storage tanks on the roof of the selected house that were given serial numbers from 1 to 7 . The collected drinking water samples were subjected to intensive examinations of physical and chemical characteristics according the Standard Methods [APHA, 2005] ${ }^{(19)}$.

\section{Sampling procedures}

Samples were collected in sterile bottles and transported in ice-box at temperature of $4^{0} \mathrm{C}$. Temperatures and free residual chlorine concentrations were immediately determined on spot and before storing according to procedures in the Standard Methods [APHA, 2005] ${ }^{19}$.

Effect of storing time on the level of chlorine in drinking water

This study was carried out in a laboratory experiment. In 5 jars, variable doses of chlorine were added to distilled water. The variable doses are 1, 2, 3, 4 and $5 \mathrm{mg} \mathrm{Cl} 2 / 1$. The jars were kept in the room temperature. The residual chlorine in each jar was detected daily for a period of 5 days. The purpose of this experiment is to detect the residual chlorine in terms of the storing period in relation to the initial concentration. 


\section{Physical and chemical characteristics}

Sodium and potassium were determined by Flame Photometer. Iron, manganese were detected by Atomic Absorption (A.A.) Spectrophotometer in the acidified water sample using Instrumental Laboratories (1L), Model 551, equipped with a heated Graphite Atomizer Model (651) and deuterium arc background corrector. The procedure of samples preparation and analysis followed the method as described in $\mathrm{APHA}^{(19)}$ and by Abdel-Shafy ${ }^{(24)}$.

Each result presented here is an average of 10 sequence readings on the Atomic Absorption (A.A) Spectrophotometer. These readings were correlated with a standard solution. Standards were purchased from the Instrumental Laboratories (1L). As control, a blank was made for each metal; using double distilled water, which was subjected to the chemical treatment and digestion similar to that of the examined samples.

\section{Results and Discussions}

\section{Drinking water resource and treatment in El-Taqaddum village}

The source of water is Nile River through Ismailia Canal that is expanded from the Delta region to Sinai. The water in the canal is raised by pump to two compact units of treatment system. The treatment process consists of alum addition followed by flocculation and sedimentation. The treated water is further sand filtered followed by chlorinated. Finally, water is pumped to the storing tanks at a height of about $8 \mathrm{~m}$. These storing tanks are connected to the water distribution system. Schematic diagram of the treatment system is illustrated in Fig. 1. It is worth to mention that the supply of the canal water to the drinking water treatment plant is continuous for 6 days only followed by other 6 days for irrigating the agriculture activities of the village (i.e. the drinking water treatment plant receives Nile water at a rate of 6 days only every 12 days). It is witnessed that sometimes the drinking water treatment plant does not receive any water supply for 9 to 11 days.

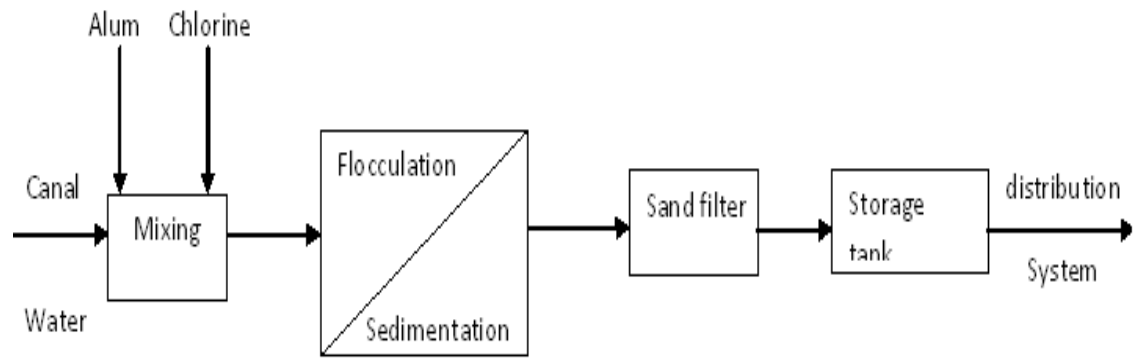

Fig.1. The successive treatment steps in the drinking water treatment plant at ElTaquaddum regional area.

Egypt. J. Chem. 59, No. 2 (2016) 
Quality of the freshly treated drinking water in El-Taqadum village

Results of the present investigation are recorded in Tables 1 and 2. The given results indicate narrow monthly variation in the studied parameters.

Table 1 represents the physical/chemical parameters. The following parameters were determined: the total dissolved solids (TDS), chlorides, residual chlorine, total-solids (TS), hardness, nitrites, nitrates and phosphates. The determined physical parameters are: $\mathrm{pH}$, temperature, turbidity and electric conductivity. From the given results (Table 1), it is apparent that the $\mathrm{pH}$ values ranged from 6.8 to 8.2 with an average of 7.2 as indication of neutral value. These values are within the recommended guideline that is ranged from 6.5 to 9.2 according to EEAA $(2000)^{(20)}$. The turbidity ranged from 0.10 to 0.78 NTU with an average of $0.45 \mathrm{NTU}$. The maximum acceptable level is 1 NTU. The electric conductivity of the studied water ranged from 280 to $450 \mu \mathrm{S}$ with the average of $364 \mu \mathrm{S}$. The guideline value is $2000 \mu \mathrm{S}$.

Total dissolved solids (TDS) ranged from 160 to $245 \mathrm{mg} / \mathrm{l}$ with an average of $200 \mathrm{mg} / \mathrm{l}$ (Table 1). Chlorides ranged from 20.1 to $38.8 \mathrm{mg} / \mathrm{l}$ with the average of $24 \mathrm{mg} / \mathrm{l}$. The maximum acceptable levels are 1200 and $500 \mathrm{mg} / \mathrm{l}$ for TDS and chlorides, respectively according to EEAA $(2000)^{(20)}$. However, the WHO $(1993)^{(21)}$ guideline for chloride is $250 \mathrm{mg} / \mathrm{l}$ as an international reference point for standard setting and drinking-water safety. The total solids ranged from 235 to 110 with an average of $167 \mathrm{mg} / \mathrm{l}$.

Other chemical parameters including total hardness, calcium hardness and magnesium hardness were investigated (Table 1). The determined average value of these parameters was 117,69 and $51 \mathrm{mg} / \mathrm{l}\left(\right.$ as $\left.\mathrm{CaCO}_{3}\right)$ respectively. The corresponding guideline of such parameters (Table 3) is 500, 200 and 150 successively (EEAA, 2000) ${ }^{(20)}$. Nitrates ranged from 0.20 to $0.02 \mathrm{mg} / \mathrm{l}$ with average of $0.12 \mathrm{mg} / \mathrm{l}$. The guideline is $44 \mathrm{mg} / \mathrm{l}$ (EEAA, 2000) ${ }^{(20)}$. The results (Table 1) showed that the nitrites and phosphates were all below detection level all study period and in all the studied sites.

Level of $\mathrm{Fe}, \mathrm{Mn}, \mathrm{Na}, \mathrm{K}$ and $\mathrm{Al}$ in the collected drinking water samples are given in Table 2. The average level of iron, manganese, sodium, potassium and aluminum was $0.22,0.18,8.26,1.40$ and $0.14 \mathrm{mg} / \mathrm{l}$, respectively (Table 2). The range of these ions in the studied drinking water ranged from 0.28 to $0.13 \mathrm{mg} / \mathrm{l}$ for iron, from 0.34 to $0.12 \mathrm{mg} / \mathrm{l}$ for $\mathrm{Mn}$, from 12.8 to $5.7 \mathrm{mg} / \mathrm{l}$ for sodium, from 2.9 to $1.0 \mathrm{mg} / \mathrm{l}$ for potassium and from 0.20 to $0.02 \mathrm{mg} / \mathrm{l}$ for aluminum (Table 2). The acceptable guideline of these metal ions in drinking water is $0.30 \mathrm{mg} / \mathrm{l}$ for $\mathrm{Fe}, 0.10 \mathrm{mg} / \mathrm{l}$ for $\mathrm{Mn}, 200 \mathrm{mg} / \mathrm{l}$ for $\mathrm{Na}$ and 0.20 for Al (EEAA, 2000) ${ }^{(20)}$ (Table $3)$. From these results it can be concluded that the detected characteristics of drinking water samples are within the acceptable levels according to the Egyptian regulation (EEAA, 2000) ${ }^{(20)}$. 


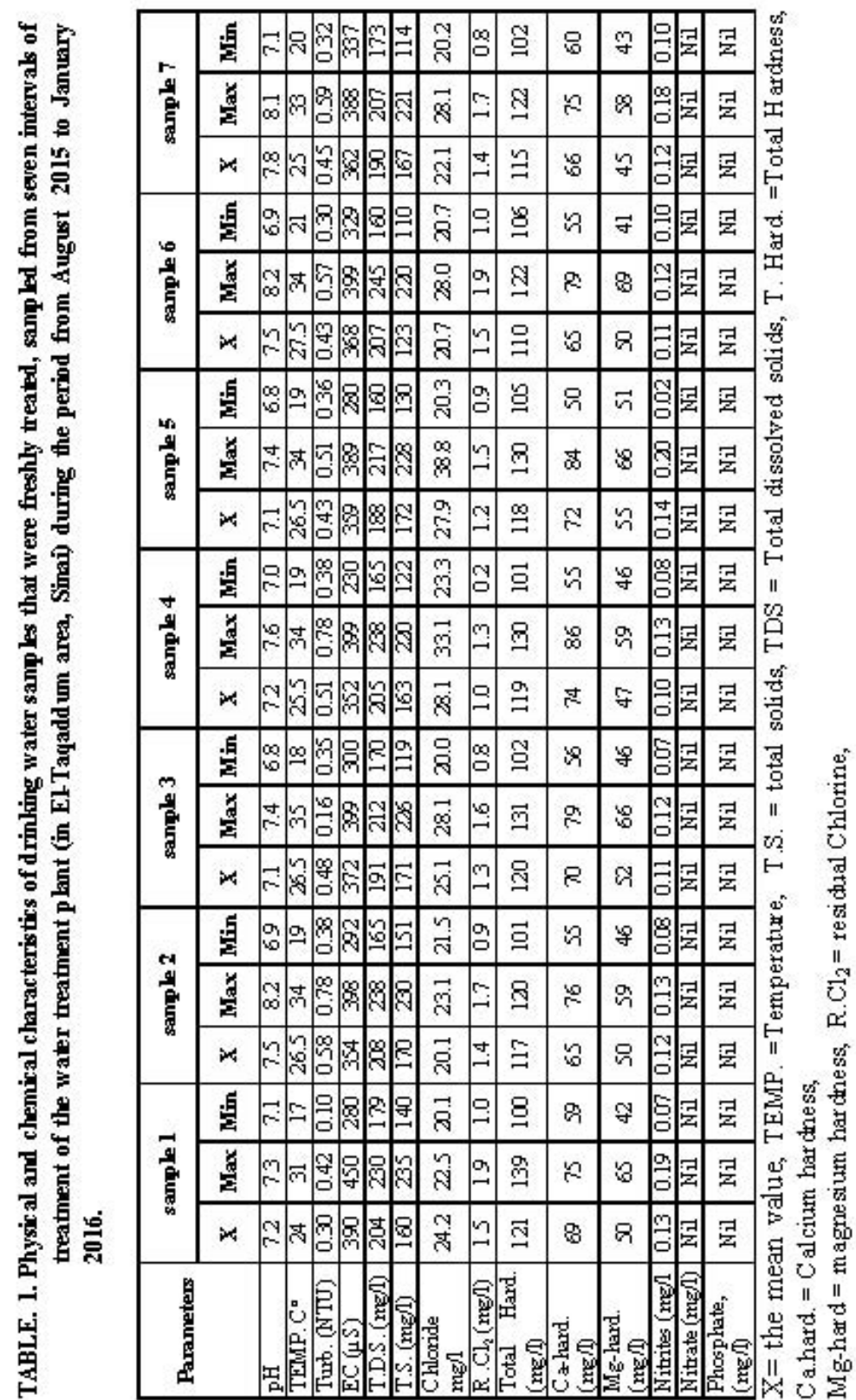




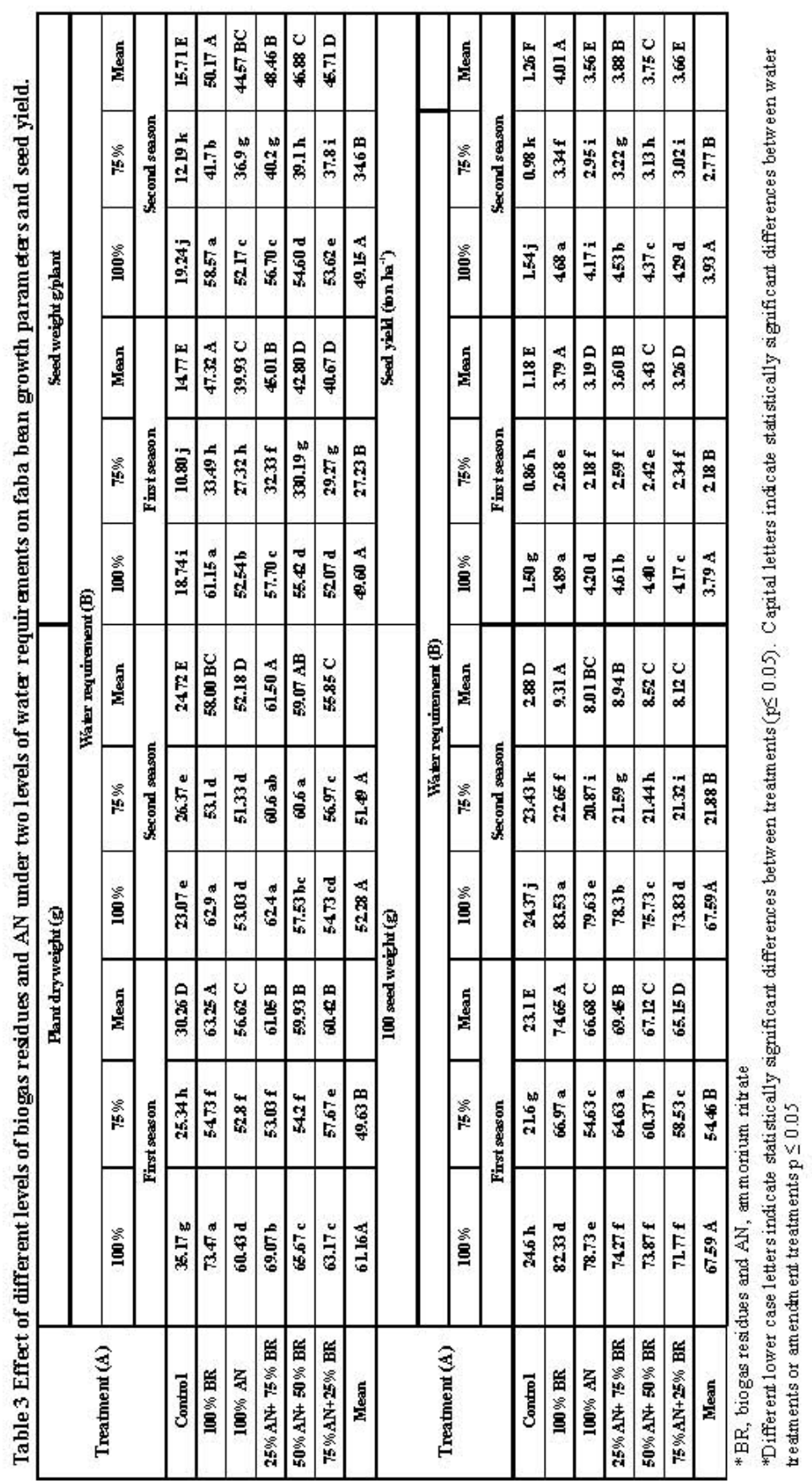


On the other hand, the total calcium and magnesium hardness (Table 1) are within the acceptable values, which is an indication of reasonable level of water quality as a "Moderately Soft" water according to EEAA $(2000)^{(20)}$.

Residual chlorine ranged between 0.2 to $1.5 \mathrm{mg} \mathrm{Cl} / 1$ in the freshly treated drinking water. From these results it can be observed that the level of chlorine of all the studied samples is within the acceptable range for safe drinking water as mentioned in the EEAA regulation $(2000)^{(20)}$.

The recorded data (Table 2) showed that the level of the studied metals can be arranged according to the following magnitude order of $\mathrm{Na}>\mathrm{K}>\mathrm{Al}>\mathrm{Fe}>$ $\mathrm{Mn}$, respectively. It can also seen that the concentrations of metals in these samples are within the acceptable levels of potable water according to the WHO $(1993)^{(21)}$.

Effect of storing time on the level of chlorine in drinking water

The results (Table 4) showed that the residual chlorine decreases by increasing the storing time. Storing drinking water for one day decreased the $\mathrm{Cl}_{2}$ initial concentration of $1,2,3,4$ and $5 \mathrm{mg} \mathrm{Cl}_{2} / 1$ to the level of $0.3,0.9,1.3,2.1$ and $2.9 \mathrm{mg} \mathrm{Cl}_{2} / 1$ as residual chlorine. Increasing the storing time up to 3 days decreased the corresponding residual $\mathrm{Cl}_{2}$ down to zero with respect to all jars, with the exception of jar No. 5 in which the initial $\mathrm{Cl}_{2}$ concentration was $5 \mathrm{mg} / \mathrm{l}$. Increasing the storing time to 4 days showed that the residual $\mathrm{Cl}_{2}$ concentration reached zero in all jars.

TABLE 4. Effect of storing time on the level of chlorine in drinking water (laboratory experiment)

\begin{tabular}{|c|c|c|c|c|c|}
\hline \multirow{2}{*}{$\begin{array}{c}\text { Time (Day) } \\
\text { Zero }\end{array}$} & \multicolumn{5}{|c|}{$\begin{array}{l}\text { Residual chlorine concentration in drinking water } \\
\qquad\left(\mathrm{mg} \mathrm{Cl}_{2} / \mathrm{L}\right)\end{array}$} \\
\hline & 1 & 2 & 3 & 4 & 5 \\
\hline 1 & 0.3 & 0.9 & 1.3 & 2.1 & 2.9 \\
\hline 2 & 0.1 & 0.5 & 0.6 & 0.9 & 1.2 \\
\hline 3 & zero & zero & zero & zero & 0.7 \\
\hline 4 & zero & zero & zero & zero & zero \\
\hline
\end{tabular}

From this experiment it can be concluded that storing the drinking water for 5 days is absolutely unacceptable due to the crucial decrease in the residual $\mathrm{Cl}_{2}$, even at an initial concentration of $5 \mathrm{mg} \mathrm{Cl} / 2$. The most possible solution is to maintain an initial $\mathrm{Cl}_{2}$ concentration at $2 \mathrm{mg} / \mathrm{l}$ and the storing period should not exceed 2 days. 
The allover results reveal that the characteristics of the freshly treated drinking water are within the permissible levels as recommended by the Egyptian EEAA regulation (2000) $)^{(20)}$ and the WHO (1993) ${ }^{(21)}$. However, storing such water for long period could cause a dramatic effect on the water quality.

\section{Recommendation}

It is worth mentioning that drinking water is, usually, stored in each house of this village for about 5 days and sometimes the storing period could reach 11 days or more. It is strongly recommended that the drinking water of this village and the surrounding area should be freshly supplied. A continuous follow up of the physical, chemical and biological examination should be carried out for the protection of the residents.

The present investigation showed that the most possible solution is to maintain an initial $\mathrm{Cl}_{2}$ concentration at $2 \mathrm{mg} / \mathrm{l}$ and the storing period should not exceed 2 days. To make this clear, residual chlorine in all drinking water supply should be within the permissible limits for safety of the residents. Otherwise, outbreak of epidemic diseases could be at high risk for these poor residents.

Acknowledgement: The author wishes to express his deep appreciation and gratitude to the fund provided by the project titled "Sustainable Development for Wastewater Treatment and Reuse via Constructed Wetlands in Sinai (SWWTR)" that is funded by STDF of Egypt.

\section{References}

1. Tackholm, V., Students' Flora of Egypt. Cairo University: Beirut Publishing (1974).

2. Gibbali, M.A., Studies on the flora of northern Sinai. M.Sc. Thesis. Fac. Science. Egypt: Cairo Univ. p. 393 (1988).

3. Boulos, L., Flora of Egypt. Geraniaceae-Boraginaceae, Vol. 2. Cairo, Egypt: Al Hadara Publishing; (2000).

4. Serag, M.S. and Khedr, A.A., Vegetation-environment relationships along El-Salam Canal, Egypt. Environmetrics, 12, 219-32 (2001).

5. Othman, A.A., Amer, M.W., Fayez, M., Monib, M. and Hegazi, N.A., Biodiversity of diazotrophs associated to the plant cover of north Sinai deserts. Arch Agron Soil Sci. 49, 683-705 (2003)

6. Othman, A.A., Amer, M.W., Fayez, M., Monib, M. and Hegazi, N.A., Biodiversity of microorganisms in semi-arid soils of north Sinai deserts. Arch Agron Soil Sci, 49,241-60 (2003).

7. El-Degwi, A.M.M., Ewida, F.M. and Gawad, S.M., Estimating BOD pollution rates along El-Salam canal using monitored water quality data (1998-2001). In:

Egypt. J. Chem. 59, No. 2 (2016) 
Proceedings of 9th International Drainage Workshop, Paper No 50. The Netherlands, Utrecht, September 10-13; (2003).

8. Abdel-Shafy, H.I. and Mansour, Mona S.M., Overview on water reuse in Egypt: Present and future. J. Sustainable Sanitation Practice, 14, pp. 17-25 (2013).

9. Mostafa, A.M., Development of water quality indicators and Atlas of drainage water quality using GIS tools. CIDA-DRTPCMWRI. Technical report submitted to the NAWQAM project- Egypt; p. 85 (2002).

10. Mostafa, A.M., Gawad, S.T. and Gawad, S.M., Development of water quality indicators for Egyptian drains. ICID, Montreal, Canada, Paper No. Q50/R6.01; (2002).

11. Mostafa, A.M., GIS analysis of the NWQM data with emphasis on WWTP. CIDADRTPC-MWRI. Technical Report Submitted to the NAWQAM Project-Egypt; p. 151. (2001)

12. Rabeh, S.A., Monitoring of microbial pollution in El- Salam Canal, Egypt. J. Egypt. Acad. Soc. Environ. Develop. 2,117-27 (2001).

13. Abou Rayan, M., Djebedjian, B. and Khaled, I., Water supply and demand and a desalination option for Sinai, Egypt. Desalination, 136, 73-82 (2001).

14. Abdel-Shafy, H.I. and Aly R.O., "Wastewater Management in Egypt" In "Wastewater Reuse-Risk Assessment, Decision-Making and Environmental Security" Mohammed K. Zaidi (Ed) Springer Publisher, Netherland, pp.375-382 (2007).

15. Abdel-Shafy, H.I., Al-Sulaiman, A. M. and Mansour, Mona S.M., "Greywater treatment via hybrid integrated systems for unrestricted reuse in Egypt. Journal of Water Process Engineering, 1, p.p. 101-107 (2014), http:// dx.doi. org/10. 1016/ j. jwpe. 2014. 04. 001

16. Hafez, A. and El Manharawy, S., Economics of seawater RO desalination in the Red Sea region, Egypt. Part 1. A case study. Desalination, 153, 335-347 (2002).

17. Abdel-Shafy, H.I. and Aly, R.O., "Water issue in Egypt: resources, pollution and protection endeavors. Central European J. of Occupational \& Environ. Medicine, 8 (1), 1-21 (2002).

18. Khalil, E., Water strategies and technological development in Egyptian coastal areas. Desalination, 165, 23-30 (2004).

19. APHA, AWWA and WEF, Standard Methods for the Examination of Water and Wastewater, 21st ed., American Public Health Association, Washington, DC, (2005).

20. EEAA - Egyptian Environmental Association Affair, Law 48, No. 61-63, Permissible values for wastes in River Nile (1982) and Law 4, Law of the Environmental Protection (1994)-updating No.(44), (2000).

21. World Health Organization (WHO) Guidelines for Drinking-water Quality, set up in Geneva, (1993).

Egypt. J. Chem. 59, No. 2 (2016) 
22. Abdel-Shafy, H.I., El-Saharty, A. A., Regelsberger, M. and Platzer, C., Rainwater issue in Egypt: quantity, climatic effect and future overlook. J. Mediterranean Marine Science, 11, (2), pp. 245-257 December (2010).

23. Abdel-Shafy, H.I., Abu-El-Wafa, O. and Azzam, A.M. "Role of fertilizer wastewater on the contamination of Ismailia canal by heavy metals" Proceed. International Conference-Heavy Metals in the Environment, New Orleans, USA, Sept., 1987, pp. 454-456 (1987).

24. Abdel-Shafy, H.I.,Chemical treatment for removal of heavy metals from industrial wastewater. Egypt. J. Chemistry, 58, (1) 1-12 (2015).

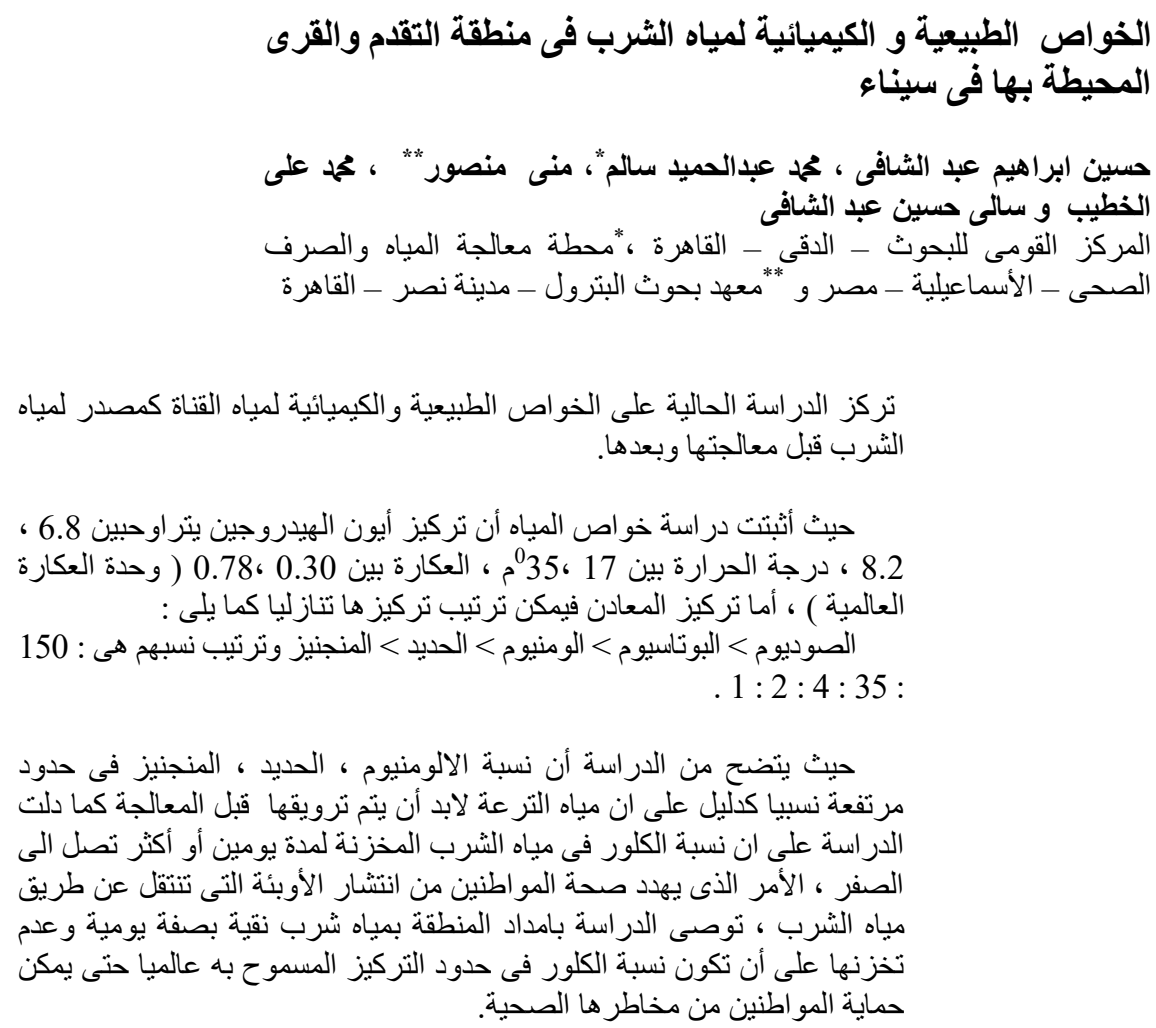

